Revista de Estudios Histórico-Jurídicos

[Sección historia del derecho patrio chileno]

XXXVII (Valparaíso, Chile, 2015)

[pp. 295 - 321]

\title{
LA HISTORIA DEL DERECHO EN LA OBRA DEL JURISTA Y POLÍTICO LIBERAL CHILENO JOSÉ ViCTORINO LASTARRIA*
}

[The History of Law in the Work of the Chilean Lawyer and Liberal Politician José Victorino Lastarria]

\author{
Felipe Ignacio Westermeyer Hernández** \\ Universidad de Chile, Santiago, Chile
}

\begin{abstract}
RESUMEN
El artículo sistematiza los planteamientos de carácter histórico-jurídico del profesor de derecho constitucional y político liberal chileno José Victorino Lastarria. Dichos planteamientos se vinculan con el
\end{abstract}

Abstract

This article systematically arranges the historical-legal approaches of José Victorino Lastarria, Chilean Constitutional law professor. Said approaches are related to the political project, aimed at deeply

ReCibido el 8 de diciembre de 2014 y ACEPTADO el 1 de julio de 2015

* Este artículo se enmarca dentro del proyecto de investigación presentado en el XVII Congreso de la Asociación de Historiadores Latinoamericanistas Europeos, efectuado en la Universidad Libre de Berlin entre los días 9 y 13 de septiembre de 2014. El autor agradece las observaciones realizadas por los profesores Raúl Andrade, Miriam Galarce, Humberto Morales, Nuria Salas y Gustavo Adolfo Vaamonde. Asimismo agradece las correcciones efectuadas en Chile por el profesor Antonio Dougnac Rodríguez y los materiales remitidos por el profesor Carlos Salinas Araneda y por su ayudante Ignacio Sánchez Bustos. Una mención especial a la bibliotecaria de la Facultad de Derecho de la Universidad de Chile, señora Gioconda Pulgar, quien de manera completamente desinteresada reprodujo y escaneo una serie de textos y fuentes sin los cuales la realización de esta investigación hubiese sido imposible. El autor también agradece a su Tandempartner de la Ruprecht-Karls Universität Heidelberg, el estudiante de Historia y Ostasiatischen Wissenschaft, señor Niklas Geberding, por su orientación, opiniones y sugerencias sobre el tema acerca del desarrollo de la dogmática jurídica en la Europa Central. Todos los errores son única y exclusiva responsabilidad del autor.

** Licenciado en ciencias jurídicas y sociales por la Universidad de Chile. Ayudante de historia del derecho en Facultad de Derecho de la Universidad de Chile. Legum Magister in Rechtswissenschaft por la Ruprecht-Karls Universität Heidelberg. Correo electrónico: westermeyer.felipe@gmail.com - westermeyer.felipe@gmail.com 
proyecto político que este suscribió el año 1850. Tal proyecto implicaba introducir una serie de profundas modificaciones en la Constitución de 1833. Por esa razón, el autor usó la historia del derecho como medio para deslegitimar la herencia cultural hispana y el derecho indiano.

\section{Palabras Clave}

José V. Lastarria - Constitucionalismo gaditano - Constitución mixta - Monarquía constitucional - Monarquía absoluta - República. modifying certain parts of the 1833 Constitution, signed in 1850 . For this reason, the author used the history of law as a means to delegitimize the Hispanic cultural heritage and the Laws of the Indies.

\section{KEYWORDS}

José V. Lastarria - Gaditan Constitutionalism - Mixed Constitution - Constitutional Monarchy - Absolute Monarchy - Republic.

\section{LA PERSONA DE JOSÉ VICTORINO LASTARRIA Y SU PLANTEAMIENTO POLÍTICO}

José Victorino Lastarria desempeñó múltiples roles en el devenir de Chile en el siglo XIX: jurista, parlamentario, profesor de derecho, diplomático, tratadista y político. Su influencia en el desarrollo cultural de Chile fue enorme ${ }^{1}$. Su trabajo en ese sentido gravitó en torno a dos ejes: fortalecer las bases de la doctrina política y económica liberal y formar una cultura de carácter nacional. Ambos objetivos partían de una base común: Chile debía acercarse a Europa y a América, renegando de la herencia cultural española.

Esta última es vista por él como la antítesis de la modernidad y la causa remota de todos los problemas que padecía la sociedad chilena. En lo jurídico esos objetivos se concretizaron en el cultivo del derecho público como disciplina autónoma de las otras ramas del derecho y, en lo político, tanto mediante la elaboración del programa político del liberalismo en Chile, el año 1850, como en su larga trayectoria como parlamentario, escritor y diplomático, y por la publicación de varios libros. Ambas tareas, la jurídica y la política, se tocaron en muchísimas ocasiones.

En cuanto a su rol como profesor, tratadista de derecho constitucional y jurista, el profesor Javier Barrientos Grandón lo define como un hombre de derecho, de sólida formación, basada en el estudio de la legislación y de los tratadistas europeos en boga. Valora en Lastarria haber sido el primero que se esmeró en delimitar claramente qué era y qué debía ser el derecho público en Chile². Dicho autor señala que a lo largo de su vida recogió primero la influencia de Jeremías Bentham, para luego abandonar a este por Enrique Ahrens, adoptando por último las ideas de Comte. Por su parte, Paulino Varas Alfonso agrega a Benjamin Constant como

\footnotetext{
${ }^{1}$ Entre libros, artículos de prensa y publicaciones de carácter periódico su obra asciende a alrededor de 270 escritos. Una recopilación completa se puede ver en De Ávila MARTeL, Alamiro - Rebolledo Hernández, Antonia, "Bibliografía." En VV. AA., Estudios sobre José Victorino Lastarria (Santiago, Ediciones Universidad de Chile, 1988), pp. 27 ss.

${ }^{2}$ Barrientos Grandón, Javier, Lastarria y el derecho, en VV. AA., Estudios sobre José Victorino Lastarria, cit. (n. 1), p. 91 ss.
} 
uno de los intelectuales y hombres de derecho que tuvo mayor gravitación en su desarrollo intelectual ${ }^{3}$.

En lo que respecta a la segunda de sus tareas, en el año 1850 junto al futuro presidente de Chile, Federico Errázuriz Zañartu, redactó las "Bases de la Reforma," nombre que se dio al programa del partido liberal, denominado por ellos mismos como "partido progresista." Su objetivo era la realización de la república en Chile. Dicha meta implicaba la realización de una serie de modificaciones al ordenamiento jurídico vigente en Chile y a la Constitución de 1833, que se podrían resumir como: limitación a la efectiva autoridad del ejecutivo mediante una nueva regulación de los estados de excepción; leyes de imprenta que estimulasen el debate y garantizasen la libertad de expresión; una legislación electoral que posibilitase una ampliación de los derechos políticos; un mejor control de los funcionarios públicos en el ejercicio de sus funciones; mayor autonomía de los municipios; codificación civil, procesal, penal y comercial; procedimientos judiciales de carácter público, una mayor instrucción moral y religiosa; el fomento de la instrucción primaria y una mejor educación para las mujeres.

El programa del partido liberal también abarcaba aspectos del gobierno espiritual, como la protección del matrimonio mixto y una reforma completa a la estructura tributaria, a fin de, entre otros objetivos, poder derogar el diezmo y posibilitar que el Estado se hiciese cargo de la mantención de los párrocos e instituciones de beneficencia, a fin que estos se pudiesen abocar completamente a sus labores educativas, pastorales y asistenciales.

En otras palabras apuntaban a una desconcentración del poder, a un mejor control de este y a la superación de la mentalidad indiana. Tan concisos objetivos implicaban poner en tela de juicio todo el ordenamiento jurídico, revisarlo a fin de implementar la república, sobre todo, introducir instituciones hasta ese momento ajenas a nuestra idiosincrasia jurídica, reformular las existentes, que no habían funcionado de acuerdo a lo esperado y reformar otras.

Entre las nuevas instituciones se pueden mencionar las acusaciones constitucionales, las interpelaciones parlamentarias, los votos de censura y una sanción penal retributiva, rehabilitadora y respetuosa de la dignidad humana.

Entre las instituciones que debían ser reformadas o derechamente reformuladas se contaban la presidencia de la república, el parlamento, -foro de discusión y debate por antonomasia-, la nacionalidad, la ciudadanía, el poder judicial, el derecho civil, el comercial y el penal.

Tales cambios eran mucho más que una reformulación del derecho indiano. Esas reformas implicaban trastocar gran parte de la institucionalidad existente. El autodenominado partido progresista no estaba conforme con el liberalismo moderado de los gobiernos pelucones. El reformismo ilustrado del conservadurismo y sus modificaciones de carácter gradual no llenaban las expectativas de su sector.

Las reformas que ellos buscaban eran un verdadero salto. Por ende, los riesgos

${ }^{3}$ Varas Alfonso, Paulino, Homenaje a los profesores José Victorino Lastarria y Jorge Hunneus en los 170 años de enseñanza del derecho constitucional, en Revista de Derecho Público, 79 (2013), p. 234.

${ }^{4}$ Texto completo disponible en el sitio web www.memoriachilena.cl 
de un fracaso político mayúsculo no eran menores. Atendida esa situación Lastarria entendió que había que buscar algún engarce entre ese cúmulo de reformas, las tradiciones inveteradas del pueblo y los valores que los representantes de su tendencia política le proponían al país. ${ }^{5}$ Dicho ejercicio no fue exclusivo del liberalismo chileno. En cada país el constitucionalismo y el liberalismo buscaron distintas formas de engarzarse con las tradiciones y costumbres. Lo que varió de un país a otro fue la forma de hacerlo.

En Chile, el primero que hizo un trabajo ideológico en esa dirección fue José Victorino Lastarria. Él lo hizo usando la historia constitucional y construyendo una interpretación de esta disciplina, en la que constitución y libertad son sinónimos.

Tal ejercicio implicó una ruptura respecto a las historias constitucionales hasta ese momento escritas. Mientras Ramón Briseño ${ }^{6}$ y Claudio $\mathrm{Gay}^{7}$ intentaron reconstruir de manera cronológica y fidedigna los acontecimientos de los primeros lustros de vida independiente de Chile, Lastarria lo que hace es una interpretación de ella en la que hay una escasa valoración por el pasado en cuanto tal y muy poco interés en atenerse a lo que de los hechos, criterios y circunstancias se desprende. El juzgaba el pasado de acuerdo a las necesidades, ideas y criterios de la época que le tocó vivir. Por esa razón se puede aventurar que su interés por la historia era más bien adjetivo. El creía que lo importante era extraer del pasado lecciones y principios a fin de mejorar el presente. La historia debía -según su opiniónestudiarse y escribirse acorde con las necesidades de la época presente. El mismo se reconocía un filósofo de la historia.

Atendido lo anterior, el uso que Lastarria hace de datos, fechas y citas no es riguroso. Sistemáticamente evita definir conceptos tales como conservador, liberal y progresista.

Por todo ello su obra carece de valor historiográfico; pero no por ello deja de ser un objeto de estudio interesante, toda vez que vino a suplir un importante vacío que hasta ese momento existía en materia de teoría constitucional, filosofía política e historia de las ideas.

Así sus libros, Investigaciones sobre la influencia social de la conquista y el sistema colonial de los españoles en Chile, de 1844; Bosquejo histórico de la constitución del gobierno de Chile, de 1847 e Historia constitucional del medio siglo, de 1853, logran en su conjunto vincular el constitucionalismo en su dimensión internacional ${ }^{8}$ con la historia patria.

\footnotetext{
${ }^{5}$ En este punto Lastarria siempre tenía presente que en México el pueblo se sintió amenazado en sus creencias y por ello tomó las armas. La religión estaba fuertemente arraigada en ese pueblo y por ello la mejor solución fue un acuerdo entre independentistas y liberales por una parte, y los defensores de la fe y la Iglesia católica por otro: LASTARRIA, José Victorino, Historia constitucional de medio siglo (Santiago, Imprenta del Mercurio, 1853), p. 320.

${ }^{6}$ BrIseño, Ramón, Memoria Histórico-critica del derecho público chileno desde 1810 hasta nuestros días. Obra presentada a la Universidad de Chile en la sesión solemne del 14 de octubre de 1849, con la que celebró el sexto aniversario de su instalación (Santiago, Imprenta de Julio Belin, 1849).

${ }^{7} \mathrm{GAY}$, Claudio, Historia fisica y política de Chile, según documentos adquiridos en esta República durante doce años de residencia en ella y publicada bajo auspicios del supremo Gobierno (Paris, Casa del Autor. En Chile Museo de Historia Natural, 1844-1876), VIII.

${ }^{8}$ Con esto queremos hablar del constitucionalismo en cuanto fenómeno global; es decir,
} 
De ese modo, Lastarria partía del hecho que las constituciones escritas eran el más alto grado de civilización al que un pueblo podía llegar ${ }^{9}$. En consecuencia, aprecia a su siglo, el XIX, como aquel en que la humanidad había alcanzado el más alto grado de civilización. En ese siglo Chile había entrado por completo, tras la guerra de la independencia, en el club de las naciones civilizadas. Lo más indicativo de ese cambio era que desde un primer momento los patriotas se abocaron a la redacción de una carta fundamental ${ }^{10}$.

Mediante las constituciones escritas los países entraban en la senda del progreso. De ese modo, Lastarria pensaba que la historia constitucional era el medio para conocer el "grado de cultura y la situación moral y política en que se halla un pueblo" ${ }^{11}$. El consideraba que las constituciones eran el espíritu mismo del pueblo.

Ciertamente esas afirmaciones, más allá de las exageraciones en las que incurre $^{12}$, distaban mucho de ser compartidas por la mayoría de la población. Durante las primeras décadas del siglo XIX en toda la América española las constituciones fueron las primeras manifestaciones del derecho patrio. Esos textos, como se verá más adelante, parecían para muchos extraños aún en los años en que los libros arriba citados fueron publicados. En consecuencia, no bastaban para esos efectos dar un discurso que legitimase a los nuevos Estados ante su población ${ }^{13}$. Tampoco bastaba el mero actuar político.

Había que generar una leyenda, construir un mito. Había que dar una nueva identidad en base a la nación ${ }^{14}$. Liberalismo y nacionalismo como ideologías se desarrollaron en Europa y Latinoamérica de manera casi simultánea durante el siglo XIX. Ambas ideologías se retroalimentaban pues en las dos el concepto de nación terminó jugando un rol importante. Lastarria entendió ese problema muy bien. Por ello lo que se propuso con esos libros fue vincular la guerra por la independencia con la lucha contra la monarquía, el despotismo y el abuso. Asimismo,

los estudios doctrinarios, el uso del derecho comparado, y la instauración de un determinado sistema de valores, que con matices más o matices menos se propaló por Europa y América.

${ }^{9}$ Lastarria, José Victorino, Historia de la Constitución del Gobierno de Chile durante el primer periodo de la revolución desde 1810 hasta 1814 (Santiago, Imprenta Chilena, 1847), p. 2.

${ }^{10}$ Ibíd. El libro completo se esmera en demostrar esa tesis.

${ }^{11}$ Ibíd., pp. 2-3.

${ }^{12}$ Célebre es a ese respecto el escrito "Constituciones", de don Andrés Bello, publicado en el periódico "El Monitor Araucano” el año 1848, en el que Bello rebate la afirmación de que las constituciones emanarían del corazón del pueblo. Bello postula que "las constituciones, la mayor parte de las veces, son obra de la parcialidad dominante o son engendradas en la soledad de un gabinete por hombre que ni aun representan a un partido". Versión del texto disponible en Bello, Andrés, Escritos jurídicos, politicos y universitarios (Squella Narducci, Agustín compilador, Valparaíso, EDEVAL, 1979) p. 35 ss.

${ }^{13}$ Tal situación no era un problema menor, pues los estados americanos recién empezaron a gozar del reconocimiento internacional de países europeos, la Santa Sede y la misma España en la década de 1840 .

${ }^{14}$ Dicha tarea era especialmente difícil en Latinoamérica, pues gran parte de los pueblos compartían elementos tales como la religión, el derecho y el idioma, que eran los que diferenciaban a las naciones europeas entre sí. De allí que entonces la historia patria y los valores por los que había luchado cada pueblo durante la guerra de la emancipación pasasen a jugar un rol fundamental en la configuración de una nueva nación. 
se propuso aterrizar en Chile la leyenda negra antiespañola y levantar una visión maniquea entre antiguo régimen y la monarquía -en el caso de Chile la Colonia y el derecho indiano- y el constitucionalismo y la república.

Todo pueblo necesita una leyenda. La de Chile sería la de la lucha por la libertad y la construcción de la República, como el nuevo orden en que los valores son la paz, la libertad, la justicia y el bien común.

En este artículo no entraremos en detalle sobre la concepción que él tenía sobre esos valores jurídicos ni sobre las bondades o defectos de la república. Lo que haremos será reconstruir los aspectos más importantes de su visión históricojurídica, matizando aquellos en los que estudios posteriores han demostrado que hay errores o exageraciones. Nos proponemos así mismo poner de relieve que hizo uso de la historia, del derecho y del derecho comparado, explorando los aspectos de su obra que lo distinguen y aquellos que merecen alguna precisión.

\section{ELEMENTOS DE SU CONSTRUCCIÓN HISTÓRICO-JURÍDICA}

a) La independencia de Chile como punto de partida de la libertad. La emancipación política fue un proceso que no encontró apoyo unánime en la población chilena. Si a ello se suma el descrédito en que cayó posteriormente el liberalismo criollo, también conocido como "pipiolaje", es entendible que lo que había en Chile hacia la década de 1830 era un Estado nuevo pero una sociedad regida aún por parámetros indianos.

Como ya se dijo, las obras históricas de Lastarria lo que buscaron fue suplir ciertos déficit en materia de filosofía política, teoría constitucional e historia constitucional.

Así, se reconoce en la independencia no solo la emancipación política, sino sobre todo, el momento en que en Chile comienza la revolución espiritual de la época contemporánea. Lastarria busca equipararla con la revolución francesa o la independencia de las 13 colonias, en cuanto hitos que significaron un cambio de época.

De ese modo constitucionalismo y liberalismo representan un sistema de valores que daría legitimidad al nuevo orden. Tales valores serían el bien común, la libertad y la justicia. Sus dotes de literato le dan a la contienda política entre esos valores, por una parte, y el privilegio y la fuerza -propios del antiguo régimen-por otra, un carácter épico. Libertad y justicia "mantienen una perpetua lucha con el despotismo y la inequidad"15. En todo el mundo ellas chocaban con las formas de gobierno que institucionalizaban la fuerza y el privilegio: los reinos e imperios. Por ende, el Chile colonial era un sistema marcado por los mencionados lastres.

Esta lucha entre ambas fuerzas espirituales también había marcado a la sociedad chilena. La historia de esta estaría jalonada por dos hitos fundamentales: la conquista y la independencia. La primera representaba la imposición de la fuerza, el abuso y la arbitrariedad; la segunda, la superación de esos vicios. Dicha

${ }^{15}$ Lastarria, José Victorino, Investigaciones sobre la influencia social de la conquista y del sistema colonial de los españoles en Chile (Santiago, Imprenta del Siglo, 1844), p. 8. 
superación se da por medio de la circulación de las ideas y del desarrollo educacional ${ }^{16}$. Él interpreta el proceso vivenciado por América Latina en el siglo XIX como un proceso de aprendizaje social y político en el que en definitiva las ideas liberales se impondrían ${ }^{17}$.

Lastarria no hace en este punto ningún engarce claro entre tradición, autonomía y nuevas ideas, sino que reconoce que la independencia no fue de inmediato sinónimo de república; que la identidad nacional no era uno de los fundamentos del movimiento y que el americanismo estuvo presente en los primeros proyectos constitucionales $^{18}$. Tal identificación se produjo, en su opinión, en primer lugar por la acción de un grupo pequeño de visionarios. En esa pléyade se encuentran José Miguel Carrera, Juan Martínez de Rosas y fray Camilo Henríquez. En su libro Bosquejo histórico de la constitución del Gobierno de Chile durante el primer periodo de la revolución, desde 1810 hasta 1814 hace también una valoración de las ideas y del trabajo de Juan Egaña ${ }^{19}$. Destaca que ellos fueron los primeros que aprendieron el constitucionalismo y que desde las esferas de poder enmendaron rápidamente los errores cometidos en los primeros años de “revolución”. El constitucionalismo simbolizaba la expansión de los derechos y las libertades, con miras a alcanzar la república democrática, esto es, el más alto estadio de desarrollo al que hasta ese momento podían aspirar los seres humanos ${ }^{20}$. Lastarria fundamenta esa aseveración en el discurso pronunciado por Martínez de Rosas en la apertura del primer congreso nacional ${ }^{21}$, en el proyecto constitucional de Egaña escrito en 1811 y publicado el año 1813, en el reglamento constitucional del año 1812 y en todos los adelantos que hasta ese momento se habrían obtenido. Es necesario advertir que sobre los aportes del primer constitucionalismo hay varias exageraciones. Así, solo a modo de ejemplo, señala Lastarria que el primer congreso nacional habría abolido la esclavitud ${ }^{22}$.

b) Constitucionalismo gaditano. José Victorino Lastarria usaba este concepto en un sentido muy amplio. Lo emplea tanto para referirse a la Constitución de Cádiz y al trabajo que en esas Cortes hicieron sus diputados, como a la irradiación de esa carta en Europa y América. El constitucionalismo gaditano impulsó cambios políticos y la dictación de nuevas constituciones en Europa y América. Su irradiación, sea como modelo constitucional a adoptar o como la excusa perfecta para reformar el sistema político y ampliar los derechos y libertades hacen que Lastarria la idealice. La transforma en un verdadero objeto de culto. La Constitución

${ }^{16}$ Ibíd., pp. 19-20.

${ }^{17}$ LaSTARria, José Victorino, Lecciones de política positiva (Santiago, Imprenta de El Ferrocarril, 1874), p. 73.

${ }^{18}$ Lastarria, J. V., Historia constitucional, cit. (n. 5), pp. 212 ss.

${ }^{19}$ Aunque la Historia constitucional da sobre Egaña un juicio bastante ambiguo, no deja de ser indicativo que en sus primeras obras lo valorase el que en ese libro transcriba completo el proyecto de Egaña. Lastarría, J. V., Bosquejo histórico de la Constitución del gobierno de Chile (Santiago, Imprenta Chilena, 1847), pp.109-207.

${ }^{20}$ Lastarria, J. V., Lecciones de politica positiva, p. 78.

${ }^{21}$ Lastarria, J. V., Bosquejo histórico, cit. (n. 19), pp. 20 ss.

${ }^{22}$ Lo que hizo el primer congreso nacional fue sólo declarar la libertad de vientre; pero ello no significó un cambio de situación jurídica de los que en ese momento eran esclavos. 
de Cádiz fue un modelo a seguir; pero la forma en la que se la recibió varió de acuerdo con las distintas culturas jurídicas. En el plano estrictamente político y literario, el constitucionalismo gaditano es presentado como símbolo de la lucha por la libertad y por la constitución: lucha contra la monarquía hispana, contra un aparato administrativo corrupto ${ }^{23}$ y también contra el invasor francés ${ }^{24}$. Luego se presenta a la Constitución de Cádiz como un verdadero instrumento redentor. Por este texto murieron hombres de valer en Galicia, Barcelona y Valencia ${ }^{25}$. La vileza de la monarquía absoluta y de la opresión que el Congreso de Viena trajo a Europa quedan muy bien ilustradas en la figura de Fernando VII y el trato que éste dio a los diputados de las Cortes de Cádiz. El hecho que con posterioridad Fernando VII haya transigido con los constitucionalistas contribuyó a cimentar la leyenda de la lucha por la libertad, y presentarla como una disputa en que siempre los liberales saldrán vencedores.

Pero una cosa es la fantasía y otra es la realidad, o mejor dicho, una cosa es el carácter político de la constitución y otra muy distinta su desarrollo dogmáticojurídico. La Constitución de Cádiz y su azarosa historia como texto vigente la transformaron en el emblema de la lucha por la libertad política, la justicia y un nuevo orden. Claro está que pocas cartas fundamentales han tenido tanta irradiación, han logrado provocar tal ola de cambios y agitaciones como la pepa. Paradójicamente es difícil encontrar otro caso en la historia en que los redactores de una constitución hayan tenido tan tristes y aciagos finales y en el que tanto esfuerzo y trabajo haya sido en vano, al menos respecto a lo que soñaban los redactores de esa Constitución. Lastarria valoraba esa carta fundamental como la más avanzada entre los textos constitucionales que consagraban la monarquía constitucional. A diferencia de los textos vigentes en Países Bajos, Baden, ${ }^{26}$ Wurtemberg ${ }^{27} \mathrm{o}$ Francia, las transacciones ideológicas a las que dio lugar el proceso constituyente gaditano otorgaron a los principios y valores del constitucionalismo un mayor reconocimiento que las citadas cartas, al punto de llegar a hacer mención a la teoría de la soberanía popular. Tal opinión se fundamentaba en la declaración de principios tales como que la nación no pertenece a ninguna familia ni persona; la soberanía reside en la nación; sólo en la nación reside el poder constituyente; el objetivo del gobierno es la felicidad de la nación y el principio de la división de los poderes del estado respetando el carácter monárquico de España. Por ello la

${ }^{23}$ Lastarria, J. V., Historia constitucional, cit. (n. 5), p. 316. En este punto se menciona el caso mexicano, en particular los intereses del grupo cercano a Iturbide.

${ }^{24}$ Ibíd., p. 87.

${ }^{25}$ Ibíd., $1^{\text {a }}$ parte, p. 167.

${ }^{26}$ Aunque Lastarria no da datos precisos acerca de ese texto, acorde con las referencias y las críticas esgrimidas, se trata de la constitución de Baden de fecha 22 de agosto de 1818. El texto consagra una teoría de origen real de la soberanía. La soberanía emana del monarca y él ha decidido otorgar ese texto a sus vasallos de Baden.

${ }^{27}$ Tampoco Lastarria entrega datos acerca del texto citado. Se trata de la Constitución de Wurtemberg de 25 de septiembre de 1819. La situación descrita en la nota anterior también se produce en este texto. 
Pepa recibe la calificación de "la primera revelación de los principios democráticos hecha en el siglo XIX ante el continente europeo" 28.

Dichos principios democráticos se encuentran también en su sistema representativo, sin resabios estamentales y marcado por una concepción de ciudadanía relativamente amplia. A eso se debe sumar la facultad otorgada a las Cortes de interpretar las leyes y la constitución. El sistema de representación y esa facultad le daban a las Cortes un poder importante, desconocido en muchas otras constituciones europeas. Sin duda eso era mucho para la década de 1810; pero no se debe olvidar que el mérito de los diputados gaditanos fue lograr fijar un mínimo a partir del cual el constitucionalismo y el liberalismo debían materializarse en el mundo de habla castellana. Tres o cuatro décadas después el desarrollo dogmático era otro y había muchísima más claridad sobre los problemas que debía solucionar el derecho constitucional. Los principios no bastaban para transformar un ordenamiento jurídico. En tal sentido, sin desconocer el correcto uso del derecho comparado, el acercamiento de Lastarria hacia esa constitución es, al menos en lo estrictamente jurídico, poco crítico.

En el plano estrictamente político, el liberalismo gaditano es para Lastarria más que lo ya señalado. Representa un triunfo de los liberales europeos frente a las coronas participantes del Congreso de Viena. Lastarria fundamentó tal afirmación en el hecho que las cortes de Cádiz obtuvieron inclusive reconocimiento por parte del zar de Rusia, generando de esta forma un conflicto con las otras casas reinantes europeas ${ }^{29}$. Con esta situación buscaba demostrar cuán fuertes eran los ideales del liberalismo hispano, al punto de haber sido capaz de descolocar a la diplomacia europea.

Paralelamente, ve al congreso de Viena como el símbolo de un mundo que se niega a morir, que representa la concentración del poder en muy pocas manos, en el que unos pocos, amparados en la tradición y la ignorancia de las mayorías, se arrogaban el derecho a decidir el futuro de cientos de miles. Las Cortes de Cádiz contra el congreso de Viena era un cuadro que retrataba muy bien la contienda política que atravesó toda la primera mitad del siglo XIX: ¿quién es el titular de la soberanía? ¿el rey, el pueblo o la nación? Más significativo aún para un escritor chileno de mediados del siglo XIX era sin embargo la figura épica que subyacía a esa contraposición: la lucha del débil contra el fuerte y poderoso. Así alimentaba esa visión maniquea entre república y monarquía.

El liberalismo gaditano es también un proyecto político que busca emancipar al hombre por medio de reformas tales como la desamortización de los bienes de los regulares y modificaciones en la estructura de la propiedad de la tierra ${ }^{30}$.

Dicho tratamiento también encontraba asidero en el que esas Cortes fueron un modelo de trabajo para otros grupos liberales a ambos lados del Atlántico,

${ }^{28}$ LASTARRIA, J. V., Historia constitucional, cit. (n. 5), p. 88.

${ }^{29}$ Ibíd., p. 175.

${ }^{30}$ Importante es destacar que el programa político del partido liberal tenía una serie de puntos de encuentro con lo que fue el proyecto de los constituyentes de Cádiz. Sólo a modo de ejemplo se pueden mencionar la desamortización de los bienes de los regulares y la exvinculación de los mayorazgos. 
como los de Nápoles, Sicilia y Portugal, mientras que para los patriotas latinoamericanos constituyó inspiración y pretexto de organización y ejercicio de autodeterminación del pueblo.

También es oportuno recordar que, en el caso de Chile, desde la década de 1830, se empezó a tejer una antinomia entre la Constitución gaditana y los textos constitucionales aquí redactados, en especial entre la pepa y la Constitución de 1833. Esta aparente antinomia es implícitamente formulada por Lastarria. Él fue extremadamente benévolo al calificar el texto de la Constitución de Cádiz y durísimo a la hora de sopesar las bondades y defectos de los chilenos.

Sobre este punto no se puede olvidar que la institucionalidad que consagran las constituciones no se corresponde siempre bien con las declaraciones de principios. Si los principios no son debidamente recibidos por la institucionalidad y la letra de la ley estos se vuelven rápidamente música celestial. No basta con que una declaración de principios sirva de criterio interpretativo. Si no se reconocen los derechos de forma extensiva ni se contempla una adecuada distribución de poder a nivel orgánico y territorial difícilmente se puede hablar de república o incluso de monarquía constitucional. En tal sentido Lastarria no hizo ningún análisis crítico de la cláusula de confesionalidad del Estado o de las restricciones a las que estaba sometida la libertad de imprenta ${ }^{31}$. Tampoco se somete a un análisis crítico la existencia de un consejo de Estado o la relación que dicha carta consagró entre la Iglesia y el Estado. En este punto parece un contrasentido criticar a las constituciones chilenas de $1818,1822,1823$ y $1833^{32}$ y no a la Constitución de Cádiz de 1812; pues está última adolecía de los mismos vicios que los ideólogos del liberalismo tanto criticaban en las mentadas cartas fundamentales de Chile.

Tampoco se hace mención ni análisis de situaciones como la ocurrida en México, donde si bien la Constitución de Cádiz sirvió de motivo para la independencia, esto sucedió porque la población quería un sistema mucho más conservador que el que ofrecía el liberalismo gaditano.

En ese mismo sentido, no deja de ser llamativo que se conceptualice a una carta otorgada como la de Bayona como democrática, por el solo hecho de consagrar el principio de la soberanía nacional..$^{33}$

No es posible saber si esta idealización fue producto de un frío cálculo político o producto de un sincero sentir. Lo que sí es entendible es que en los sectores más liberales de la doctrina constitucional chilena se haya visto a la pepa como la victoria política que en Chile les había faltado. El liberalismo gaditano buscó impulsar una serie de reformas que, a pesar de todo, tuvieron mejor suerte en la península ibérica, donde efectivamente fueron implementadas, que en el valle central de Chile ${ }^{34}$.

c) Visión sobre América. El mismo hecho de la independencia y la ne-

${ }^{31}$ La Constitución de Cádiz consagraba sólo la libertad para escribir, imprimir y publicar ideas políticas; pero la idea que existía sobre la imprenta era que debía contribuir a la instrucción del pueblo, por ello no estaban permitidas las críticas a la religión.

${ }^{32}$ Lastarria, J. V., Historia constitucional, cit. (n. 5), p. 250.

${ }^{33}$ Ibíd., p. 69.

${ }^{34}$ Solo a modo de ejemplo véase Westermeyer Hernández, Felipe, La desamortización de 
cesidad de fundar una cultura nacional independiente de la hispana alimentó en su persona un desprecio por España y una fuerte admiración por Europa. Como dice Luis Oyarzún: "España no era sino la prolongación de África en el continente europeo y América española no quería ser África. Quería ser una nueva Europa, una Europa feliz" ${ }^{35}$. La visión de Lastarria es europeo-centrista; pero no por eso dejaba de ser crítica. La misión de América era reproducir la cultura europea pero no repetir sus errores. En cuanto a derecho público se refiere, el autor en estudio percibía al continente americano como la promesa del constitucionalismo. En América se debían reproducir las nuevas ideas del derecho público, mas no los errores que Europa había cometido en sus nuevas formas de organización política. América es el lugar donde las constituciones y las instituciones de carácter liberal encontrarían las mejores posibilidades de implementación. América es el continente donde florecen las constituciones. Tan optimista posición se basaba en la experiencia europea y en su posición política liberal. La república moderna era la forma de gobierno típica de América. La república representaba la concretización de los ideales del constitucionalismo. A ojos del liberalismo latinoamericano, Europa representaba el fracaso de la república como forma de gobierno, las doctrinas erradas y la pervivencia de la monarquía. El fundamento de tal postura frente al derecho constitucional era el mayor arraigo de la tradición monárquica en Europa y el mayor desarrollo doctrinario que las ideas tradicionalistas poseían en dicho continente. Lastarria reconoce en el arraigo de determinadas ideas en un pueblo el principal aliciente o el principal obstáculo para realizar cambios políticos, sociales e institucionales ${ }^{36}$. En ese sentido, la independencia de América era mucho más que el triunfo contra España. Era la victoria de un grupo de pueblos contra todas las casas reinantes europeas ${ }^{37}$. Era además la mejor prueba de la menor fortaleza de la tradición y de su aparataje conceptual en América. El autor reconocía que la primera mitad del siglo XIX había sido sólo una larga transición desde el mundo indiano a las repúblicas, pero avizoraba un término exitoso de ese proceso. Prueba de ello era que los valores del constitucionalismo, en especial los de libertad y orden, eran aceptados a mediados del siglo XIX inclusive por caudillos. Los valores del constitucionalismo eran los valores del derecho de América ${ }^{38}$. El sabio adagio popular: "del dicho al hecho hay mucho trecho" parece que era desconocido por Lastarria.

El otro fundamento de tal optimismo era la crítica opinión reinante sobre la Revolución Francesa y sus consecuencias. "La república principia en Francia alimentándose con sangre" ${ }^{39}$ La revolución francesa era para él un experimento

los bienes de regulares en Chile: la primera discusión jurídica del derecho patrio sobre la naturaleza y alcance del dominio, en Revista Chilena de Historia del Derecho, 22 (2010) 2, pp. 1103-1129.

${ }^{35}$ Oyarzún, Luis, El pensamiento de Lastarria (Santiago, Editorial Jurídica de Chile, 1953), p. 188 .

${ }^{36}$ LASTARrIa, José Victorino, Lecciones de política positiva, cit. (n. 17), pp. 80 ss.

${ }^{37}$ Lastarria, J. V., Historia constitucional, cit. (n. 5), pp. 337 ss., a raíz del congreso de Verona.

${ }^{38}$ Ibíd., p. xi.

${ }^{39}$ Ibíd., p.8. 
fracasado. Desde la instauración del segundo imperio Lastarria experimenta una desilusión respecto de Francia ${ }^{40}$. Como seguidor del liberalismo de Benjamin Constant se escandaliza ante la tríada libertad, igualdad y fraternidad. Según Lastarria ese conjunto de valores atacaba el liberalismo y servía de fundamento a una doctrina contraria: el socialismo. Para los socialistas franceses libertad significaba propiedad, igualdad derecho al trabajo y fraternidad era sinónimo de solidaridad ${ }^{41}$.

América Latina había ganado, por el contrario, la independencia a costa de una guerra contra España pero en ningún caso dicho conflicto significó la destrucción de un país ni un baño de sangre como aconteció en Francia. Además, la libertad era el valor fundamental de este continente. El socialismo y un Estado interventor en lo económico no tenían cabida en este continente.

A lo anterior se suma una fuerte crítica tanto a la nueva forma de gobierno europea, la monarquía constitucional, como a las ideologías imperantes, en especial al socialismo en Inglaterra. La monarquía constitucional ${ }^{42}$ y la república democrática social ${ }^{43}$ son dos errores que impiden un rápido y amplio desenvolvimiento de la libertad. En ese sentido Francia, Países Bajos, Polonia, Baviera, Baden, Wurtemberg, España, Nápoles, Portugal y la república de Cracovia son vistos por Lastarria como países que tienen monarcas poderosos e irresponsables. Los monarcas detentan el ejecutivo, participan activamente de la actividad legislativa y designan a los titulares de los tribunales de justicia. En tal carácter no se puede hablar de gobiernos constitucionales sino sólo en el papel. En la mayoría de esos países los monarcas habían otorgado las constituciones. Estas carecían de un reconocimiento de los principios fundamentales del derecho constitucional

${ }^{40}$ Subercaseaux, Bernardo, La América de José Victorino Lastarria y las ideas de Courcelle Seneuill, en Revista de Derecho y Humanidades, 8 (2001).

${ }^{41}$ LastarRIA, J. V., Lecciones de politica positiva, cit. (n. 17), p. 170.

${ }^{42} \mathrm{La}$ monarquía constitucional es objeto de fuertes críticas por considerar que su diseño significaba una transacción muy costosa a los ojos del constitucionalismo. En primer lugar el monarca otorgaba la constitución. Esto significaba poner al mismo nivel el derecho divino de los reyes y el principio de la soberanía popular. Sin reconocimiento al principio de la soberanía popular se negaban, en su opinión, las bases mismas del constitucionalismo. En segundo lugar, al dejar a la monarquía en una posición muy fuerte, se mantenía el status quo. Esto es, no era posible revisar todo el sistema de privilegios construido durante años. Y por último la monarquía representaba en sí una restricción de los derechos políticos.

${ }^{43}$ Este concepto aparece citado aunque jamás explicado. Lastarria lo analiza con ocasión de los problemas suscitados en Inglaterra a raíz de la guerra contra Napoleón. Al tener Inglaterra los mercados para sus manufacturas cerrados aumentó la cesantía, hubo un encarecimiento de los productos básicos debido a la escasez y las tensiones sociales entre las distintas clases sociales se acrecentaron. En este contexto surgen los en ese momento llamados comunistas, quienes propugnan una reforma completa al sistema político inglés y una redistribución de la propiedad agraria. Dicho cambio significaba la destrucción de todo el orden conocido hasta ese momento. Por eso es que Lastarria ve en la república democrática y social un peligro no sólo para la monarquía sino también para la república. Esto pues en la mentalidad del constitucionalismo de ese entonces la propiedad es una manifestación y expresión de la individualidad y sobre todo de la libertad. Sin propiedad no hay libertad. Al querer los comunistas un régimen homogéneo buscan acabar con las diferencias entre los hombres y esto significaba destruir la nación y la familia. Como última reflexión, Lastarria se lamentaba que el concepto de república fuese tan manoseado. A cualquier organización política se la denominaba República. 
como la soberanía popular, el gobierno representativo y la división de los poderes del Estado.

Esas dos formas de gobierno propias de Europa restringían, en su opinión, el debate y las posibilidades de transacción, pues las doctrinas que sustentan -conservadurismo y socialismo- eran incompatibles entre sí e impelían soluciones violentas. El único camino del socialismo y la monarquía para asegurar su sobrevivencia es la imposición del uno sobre el otro por la fuerza ${ }^{44}$.

Los países arriba mencionados poseían, como ya se dijo, un sistema representativo, que combinaba elementos estamentales y democráticos, lo que para Lastarria parece poco serio y en ningún caso se corresponde con el constitucionalismo y los ideales de libertad. La monarquía constitucional era, en su entender, por esencia autoritaria ${ }^{45}$.

Por el contrario, Lastarria considera que una de las ventajas de la república es que todos los grupos políticos deben actuar dentro del sistema político. La república, al basarse en la igualdad, no daba pábulo a discursos que invoquen la imposibilidad de participar en el juego político. La igualdad ante la ley y la existencia de requisitos habilitantes iguales para todos, al momento de ejercer los derechos políticos, producía, a su entender, adhesión al sistema. Un sistema inclusivo, como la república, excluía el uso de la fuerza extra institucional como medio legítimo de acción política. El hecho de basarse en la igualdad significaba el rechazo a toda institución cuyo origen no esté en la nación.

De acuerdo a ese raciocinio Lastarria no concebía a la nación solo como la base del sistema y la fuente de legitimidad de todo el poder estatal, sino que también como el factor queda el carácter de iguales a todos los nacionales. Por esa misma razón rechazaba el consejo de Estado y el Senado de la Constitución de $1818^{46}$.

Dicho paraíso constitucional no quedaba en el plano político e ideológico. América Latina tenía dos modelos de constituciones republicanas y democráticas. Se trataba de la Constitución de Colombia ${ }^{47}$ y la del Perúu ${ }^{48}$. Ellas eran las más avanzadas de Latinoamérica y, a diferencia de las cartas provenientes de otras partes del mundo, éstas habían sido elaboradas de acuerdo a la realidad latinoamericana ${ }^{49}$.

El autor estudiado sabía que la implementación de una república democrática es un proceso en curso. Por esa razón no aquilata bien cuáles son las consecuencias de la anarquía posterior a la emancipación. Lastarria pensaba que la anarquía y la dictadura eran parte de un proceso de aprendizaje $e^{50}$. En su imaginario no

${ }^{44}$ Lastarria, J. V., Historia constitucional, cit. (n. 5), pp. ix-x.

${ }^{45}$ Ibíd., pp. 191 ss..

${ }^{46}$ Ibíd., p. 412. Sin embargo, parece algo contradictorio el uso de la voz aristocracia para la última institución. Sostener que el senado por el sólo hecho de tener su origen en el director supremo representa a la aristocracia del país es a todas luces una exageración.

${ }^{47}$ Por los datos y la descripción que el autor en estudio entrega presumimos que se refiere a la Constitución colombiana del año 1853, aunque no estamos del todo seguros.

${ }^{48}$ Aventuramos que en este caso se refiere a la Constitución peruana de 1828 o a la de 1834 .

${ }^{49}$ Lastarria, J. V., Historia constitucional, cit. (n. 5), p. 425.

${ }^{50}$ Emblemático de este diagnóstico es la opinión que se emite acerca de Paraguay. Se sostiene que por haber sido un país formado al alero de una monarquía absoluta, optó por alejarse del federalismo de las Provincias Unidas del Río de la Plata y darle a su conductor el título de 
concebía el surgimiento de sistemas políticos autoritarios que contasen con legitimidad social.

Ya en su madurez Lastarria moderó estas afirmaciones. Se dio cuenta que las constituciones no eran sino un instrumento jurídico típico de un pequeño número de países; que muchísimos juristas las consideran absolutamente irrelevantes, al carecer de influencia en el destino de las naciones y debido al enorme número de constituciones que tuvieron un cortísimo período de vigencia y que muchas veces lo que se intentaba era solucionar todos los problemas redactando una nueva constitución. Dicha práctica se basaba en la idea de que la nueva constitución traería estabilidad política, mediante el reconocimiento de los derechos fundamentales, y estabilidad social, pues la nueva constitución se había elaborado mediante una reforma de las instituciones políticas contenidas en las constituciones anteriores, tras largos y sesudos estudios. ${ }^{51}$ En su madurez llegó a la conclusión que las constituciones no podían ser obra de cenáculos de expertos, ignorantes de las condiciones sociales e históricas. Él terminó aceptando a regañadientes que las únicas constituciones exitosas son las que recogen con realismo las características de la sociedad en que regirán. "Es cierto que las que han conservado las leyes y hábitos politicos, reconstruyendo sobre ellas el antiguo régimen han tenido cierta estabilidad, como la constitución de Chile y la de Francia del año VIII, han consolidado la centralización administrativa" ${ }^{\text {2 }}$.

Claro está que esta conclusión no puede haber sido para el autor en estudio fácil de escribir ni de aceptar. Luego de esa conclusión afirma que ninguna de esas constituciones tenía su origen en la organización social, sino que fueron redactadas con el objeto de oprimir al pueblo. Contradictorio resulta que por una parte se les reconozca a esas cartas fundamentales el mérito de conservar costumbres jurídicas y por otra se considere que su fin era oprimir al pueblo. Nos explicamos esto en la simplificación conceptual que se hace del derecho indiano -de por sí un sistema extremadamente complejo-y por la minusvaloración del mal llamado derecho del antiguo régimen.

Es claro que Lastarria era un hombre de principios y no aceptaba que estos retrocediesen ante la realidad, pero olvidaba que ellos por sí solos no pueden cambiar la naturaleza de las cosas ni los hábitos y costumbres de un pueblo.

Para una explicación más acabada, nos remitimos a la crítica histórica que efectuaremos en los puntos atingentes al derecho indiano y a la constitución mixta.

Como Lastarria era un hombre de convicciones, después de apreciar la situación de la Constitución chilena de 1833 y estudiar las similitudes de muchas de las cartas fundamentales que duraron meses, llegó a la conclusión de que el constitucionalismo latinoamericano constituía una suerte de versión propia del constitucionalismo, distinta del europeo. En consecuencia el constitucionalismo latinoamericano padecía de vicios propios como un débil reconocimiento de los derechos sociales e individuales; la carencia de garantías efectivas para proteger

dictador perpetuo. Aislándose del resto de la cuenca del Río de la Plata dicho país habría evitado los males propios de la anarquía.

${ }^{51}$ Lastarria, J. V.. Lecciones de politica positiva, , cit. (n. 17), pp. 266 ss

${ }^{52}$ Ibíd., p. 268. 
los derechos, una idea de soberanía nacional carente de límites y una enorme concentración de poder en la figura del presidente de la república. Otro defecto de las constituciones latinoamericanas era la escasa precisión a la hora de determinar las atribuciones de los órganos políticos, lo que daba mucho espacio a la discrecionalidad. Como tercer defecto de la teoría constitucional en Latinoamérica Lastarria señala el déficit en materia de control de los gobernantes por parte de los gobernados y la falta de medios para hacer efectiva la responsabilidad de las autoridades. Por último señala que el poder constituyente generalmente no considera al pueblo en la redacción de las cartas fundamentales ${ }^{53}$.

d) El modelo inglés. El arquetipo del sistema político para Lastarria son los dos países de lengua inglesa. Inglaterra y Estados Unidos son valorados en aras de una larga tradición monárquica marcada por los acuerdos que paulatinamente restringieron las regalías del monarca y por el éxito de la revolución americana respectivamente. La única forma de monarquía que se correspondía con los valores del constitucionalismo era la constitucional inglesa y la única república perfecta era la federal norteamericana ${ }^{54}$. En las trece colonias no hubo una regresión absolutista ni una renuncia a los principios revolucionarios. El pueblo, a diferencia de Francia, adoptó un camino y no dio marcha atrás. En Estados Unidos, los principios de la revolución francesa habían sido implementados exitosamente. Bajo esa premisa se llega a sostener que Inglaterra habría dado a sus colonias solo libertades. Estados Unidos es alzado como la más perfecta concreción de los valores constitucionales. Dicho país, heredero de la tradición libertaria inglesa solo habría perfeccionado el constitucionalismo inglés. En ninguna parte hace mención a la situación de los esclavos negros en el país del norte ni al trato que recibieron los aborígenes. Sólo los españoles habrían conquistado territorios, expoliado a los aborígenes y ocupado sus tierras. Solamente los peninsulares eran portadores de defectos. Los ingleses habrían llegado a territorios que estaban absolutamente desocupados. Pareciese que en América del Norte no había habitantes antes de la llegada de los ingleses.

Frente al idealismo latinoamericano Lastarria destaca el pragmatismo de Inglaterra y Estados Unidos. Mientras la segunda nación se dedicó sólo a constituir un mandato presidencial de carácter temporal, limitado y sujeto a responsabilidades frente a los gobernados, la primera habría aprendido ya con la redacción de la carta magna del año 1215 a diferenciar entre Estado y sociedad ${ }^{55}$. Ambas naciones habían entendido que más importante que tener una constitución con elocuentes discursos preliminares era contar con los medios procesales para hacer efectiva la protección de los derechos. Ambos pueblos habían vivenciado que daba lo mismo si el que gobernaba fuese un solo hombre o una asamblea. Siempre habría despotismo político si el poder se encontraba concentrado en un solo organismo y este no estaba sujeto a un estatuto de responsabilidades frente a los gobernados ${ }^{56}$.

A partir de estas premisas transforma a Inglaterra en el arquetipo de "sociedad

\footnotetext{
${ }^{53}$ Ibíd., pp. 273-274.

${ }^{54}$ Lastarria, J. V., Historia constitucional, cit. (n. 5), p. 313.

${ }^{55}$ Lastarria, J. V., Lecciones de política positiva, , cit. (n. 17), pp. 275-276

${ }^{56}$ Ibíd., p. 287.
} 
libre y soberana desde la cuna" ${ }^{57}$. Dicha sociedad libre era la guardiana de las libertades y garantías individuales. Tal afirmación la fundamenta en el hecho que autores como Montesquieu recogieron de la tradición jurídica británica, entre otros, el principio de la separación de los poderes del Estado. Lastarria pone de manifiesto que la gran contribución de Montesquieu fue la sistematización de prácticas, hábitos y costumbres como el mentado principio, divulgándolos por medio de sus obras. Acorde con el viejo argumento de que las leyes deben adecuarse al contexto político, social y económico en el que van a regir, Lastarria planteó que el éxito del constitucionalismo en ambos países se debía a que ambas naciones, con anterioridad al siglo XVIII, consideraban imprescindible que los poderes del Estado fuesen independientes entre sí, que hubiese medios procesales para hacer efectiva la protección de los derechos y a que los gobernantes debían estar sujetos a un estatuto de responsabilidad.

Del mismo modo, en Inglaterra y Estados Unidos los ideales postulados por el constitucionalismo habían triunfado porque dichos pueblos no padecían de defectos como el fanatismo religioso, el espíritu aristocrático, la lealtad y adhesión a la monarquía, el odio y desprecio hacia lo extranjero y todo tipo de despotismos ${ }^{58}$.

e) Crítica al derecho indiano. La necesidad de fundar algo nuevo significa magnificar los defectos del sistema anterior. Existía consenso en torno a la falta de sistematización del derecho indiano, a los problemas de interpretación que acarreaba su pluralidad de fuentes y a la falta de certeza sobre cuáles eran las normas vigentes.

Asimismo, existía consenso en que el último intento de fijación de ese derecho, la Novísima Recopilación, no se correspondía con los avances de la ciencia jurídica de la primera década del siglo XIX. Las críticas al derecho indiano y la necesidad de codificar el derecho eran todo menos nuevas al momento en que Lastarria publicó los libros antes citados. Lo novedoso de su planteamiento fue superar la crítica estrictamente jurídica y llevarla al plano de los valores y de la institucionalidad heredada por el derecho patrio. La crítica de Lastarria al derecho indiano fue mucho más allá de la necesidad de una adecuada codificación, fuese esta civil, comercial, procesal o penal. Él la llevó al derecho público. Así critica al derecho indiano por no contemplar entre sus fines la igualdad y la libertad del aborigen. El trato de incapaz relativo que recibirán estos solo habría permitido mantenerlos en una situación de permanente servidumbre ${ }^{59}$.

La institucionalidad indiana es criticada por estar conformada por personas que detentaban oficios y funciones; pero no por instituciones con facultades claramente delimitadas. Para ello se cita como caso paradigmático al gobernador ${ }^{60}$.

\footnotetext{
${ }^{57}$ Lastarria, J. V., Historia constitucional, cit. (n. 5), $1^{\text {a }}$ parte, p. 23.

${ }^{58}$ Ibíd., p. 24.

${ }^{59}$ Ibíd., p. 22

${ }^{60} \mathrm{El}$ gobernador en Chile reunía las funciones de representante del soberano, era el encargado del gobierno del reino, responsable de su administración, jefe del ejército. Por su carácter de comandante era presidente de Chile. Y gobernador militar de Valdivia, Chiloé, Juan Fernández y Valparaíso. Y presidente de la Real Audiencia, del Tribunal de Hacienda, del Tribunal de Cruzada, de Tierras Vacantes y juez de comercio.
} 
Además de estas, formula las mismas críticas que el resto de la doctrina. Critica primero su ratio iuris: el objeto del derecho indiano no habría sido otro que la sumisión de todos los habitantes de la América indiana al soberano, desconocerles su calidad de personas e impedir el surgimiento de cualquier sentido de comunidad distinta de la calidad de súbdito ${ }^{61}$. El carácter casuístico del derecho indiano, su falta de sistematización, la elaboración de normas por parte de funcionarios reales que desconocían la realidad de este continente, el proceso de fijación y dispersión al que dieron lugar las sucesivas recopilaciones y el amplio margen de decisión que ese ordenamiento jurídico otorgaba a las autoridades locales son los principales reparos que ese ordenamiento jurídico merece desde una perspectiva positivista. También merecía reparos la cantidad de tribunales especiales y la discrecionalidad del juez y oidor de la Real Audiencia ${ }^{62}$. La competencia especial que distinguía a la gran mayoría de los tribunales en el mundo indiano era un obstáculo para la correcta administración de justicia. La proliferación de tribunales con competencia especial impedía una justicia rápida y eficaz. Pocos jueces se atrevían a resolver un caso en su integridad pues algunos aspectos del caso concreto siempre escapaban de su radio de competencia, o sucedía también que por medio de la interposición de cuestiones y contiendas de competencias los procesos se dilataban en demasía.

Del mismo modo, haciéndose eco de un típico argumento del siglo XIX, le merecían reparos la cantidad de estatutos especiales y la obligación que poseían los gobiernos de respetarlos. Dice: "En cualquier paso que se diese en el gobierno de América se habia de encontrar siempre el obstáculo de alguno de los muchos fueros $y$ privilegios de las corporaciones y profesiones que abundaban en ella" ${ }^{63}$.

Las sistematizaciones del derecho implican siempre un cambio en las estructuras de poder. El derecho constitucional no fue la excepción. Este era un derecho uniforme y unificador. Buscaba acabar con los derechos propios y con estatutos que con el paso del tiempo habían olvidado cuál era su fundamento y su razón de ser. El derecho constitucional decimonónico buscaba concentrar el poder en instituciones que tuvieran su origen en el poder estatal. Le desconocía potestad normativa a los grupos intermedios y le negaba valor a aquellos estatutos reconocidos por el Estado, pero cuya fuente de poder no estaba en la nación. De acuerdo a esa concepción, los grupos intermedios o aquellos que no se ajustaban al concepto estandarizado de normalidad vigente en ese momento sólo podían esperar del estado el otorgamiento de franquicias y regalías ${ }^{64}$.

Motivo de críticas fue también que en el derecho indiano los operadores políticos fuesen solo sacerdotes y abogados. Se les consideraba incompatibles con las tareas propias de un gobierno ${ }^{65}$.

La superación del derecho indiano era para Lastarria parte fundamental de su

${ }^{61}$ Lastarria, J. V., Historia constitucional, cit. (n. 5), p. 210.

${ }^{62}$ Ibíd., pp. 38-39.

${ }^{63}$ Lastarria, J. V., Investigaciones, cit. (n. 15), p. 39.

${ }^{64}$ Importante es destacar que ese peligro Lastarria lo entendió rapidamente. Por ello formuló tanto en su programa de acción política como en su libro Lecciones de política positiva el principio de la limitación de la soberanía del estado por medio del respeto a la libertad de las personas.

${ }^{65}$ Lastarria, J. V., Historia constitucional, cit. (n. 5), p. 223. 
proyecto político. La fundación de una nueva cultura jurídica basada en valores distintos a los que inspiraban al derecho indiano es una de las primeras prioridades de este movimiento. Por ello en sus obras se da la simbiosis: constitucionalismo, codificación, independencia, república, libertad, igualdad. Los seis elementos van juntos.

Es probable que la transformación jurídica y política que trajo la independencia haya provocado un shock cultural en algunos sectores de la población. Es así como Lastarria se quejaba: "No falta quien participe hasta cierto punto de la creencia y quien sostenga la sabiduría de tan monstruosa legislación, que por desgracia y no sé porque aberración inexplicable se considera vigente en una república soberana $e$ independiente, que dejó de necesitar las leyes coloniales desde el momento en que proclamó su independencia" ${ }^{66}$. Acertadas son al respecto las palabras de Bernardo Subercaseaux, citadas por Alamiro de Ávila, en el sentido que Lastarria, aunque en más de un pasaje de sus libros reconoce esa realidad, al momento de emitir juicios y evaluar el desarrollo político e institucional, no comprendía que los cambios en la conciencia social se van produciendo no por la mayor o menor fuerza de las ideas sino en virtud de intereses y relaciones sociales ${ }^{67}$.

Sobre la postura de Lastarria frente al derecho indiano es dable advertir que las críticas que esgrime eran efectivas; pero los dos siglos de vida independiente a este lado del atlántico permiten destacar también las bondades y aciertos de ese sistema.

Entre estos últimos cabe destacar el fuerte respeto por la autoridad suprema y soberana del monarca. Como señala Horst Pietschmann, también es importante tener presente que las ideas contractualistas y pactistas medievales tomaron nueva vida en la América española. Los conquistadores cruzaban el océano impregnados de esas ideas y de ellas se sirvieron. América conservó mejor ese ideario jurídico que la península Ibérica. Esas diferencias se manifestaron en conflictos entre la Corona y los conquistadores cuya solución fue la generación de un aparato burocrático que derivaría en un mediador entre las sociedades locales y el poder central $^{68}$. Por ende, volvemos a repetir que sostener que el derecho indiano era una fuente de opresión para los americanos es una simplificación extrema de la realidad. El derecho indiano generó una serie de hábitos y prácticas que de diferentes maneras pervivieron a lo largo del siglo XIX. Algunas constituciones, como se señalaba en otro punto, recogieron ese espíritu. Eso no significa que esas constituciones hubiesen sido redactadas con la intención de dominar al pueblo, sino que simplemente se hicieron cargo de una realidad y se atrevieron a heredar un sistema político cuyas formas de participación e integración eran otras.

f) Constitución mixta o jurisdiccional ${ }^{69}$. Son pocas las alusiones que

\footnotetext{
${ }^{66}$ Ibíd., pp.39-40.

${ }^{67}$ De Ávila Martel, Alamiro, cit. (n. 1), p. 20.

${ }^{68}$ Pietschmann, Horst, Actores locales y poder central: la herencia colonial y el caso de México, en Relaciones, 73, Invierno de 1998, XIX.

${ }^{69}$ Usamos este concepto para hablar de la constitución anterior a la idea de constitución formulada por el constitucionalismo. Dicha idea se corresponde temporalmente con la edad media y la primera parte de la edad moderna. Se caracteriza por una dispersión del poder, en el que todos ellos se limitaban entre sí. El poder se encuentra distribuido entre la Iglesia y el
} 
se pueden encontrar a la constitución mixta. A nivel de doctrina es escasamente mencionada. Esto no significa que la idea de una constitución mixta fuese desconocida para Lastarria. Sus fundamentos son el privilegio y la fe $\mathrm{f}^{70}$. Este concepto fue elaborado a partir de hábitos y costumbres, posteriormente analizados y fundamentados por la doctrina. Esa elaboración conceptual obedece a un desarrollo de varios siglos, tendiente a controlar el poder político mediante el derecho, la moral y la religión. En la obra de Lastarria no existe ninguna valoración de la doctrina anterior al siglo XIX: "Mientras las leyes han sido siempre inspiradas en las costumbres... no ha sucedido lo mismo en América. Aqui la ley ha precedido a la costumbre. El pueblo no estaba formado y ya existían las leyes" ${ }^{\prime 1}$. Lastarria no niega las virtudes de ese sistema, pero consideran un error pensar que el derecho indiano representa la aplicación del pactismo hispano en América. Por el contrario, la institucionalidad que fundaron los españoles no contemplaba en Chile un adecuado sistema de frenos y contrapesos que evitase la concentración del poder. El chileno no habría conocido el pactismo: solo el absolutismo en la figura del gobernador ${ }^{72}$. Las obras estudiadas consideran que esta no tenía valor en Chile pues las normas que permitían el control de los actos de gobierno no habrían tenido aplicación. El mejor ejemplo que a este respecto dan es la imposibilidad de implementar la propuesta de $1622^{73}$, producto de los intereses económicos que las autoridades

imperio, con una marcada vocación universalista; pero poco control efectivo. A estos poderes universales se agregaban los monarcas, los señores feudales, laicos y eclesiásticos, los municipios y las ciudades. El elemento determinante de esta organización es el territorio. Ninguno de estos poderes alcanzaban a regular la totalidad de los aspectos de la persona humana. Por el contrario, las relaciones de carácter económico y patrimonial se regían por el derecho consuetudinario. La dispersión del poder y la limitación de estos poderes entre sí no estaba regulada en ningún documento. Obedeció más bien a normas de carácter consuetudinario. Cada institución era celosa del mantenimiento de su statu quo. Esta distribución del poder se basaba en el principio de autoridad y en un orden jurídico ideal dado, vinculante para los hombres y para las fuerzas sociales. En esa constitución, la labor de la doctrina y del pensamiento jurídico era enorme. Se le llamaba constitución mixta pues ninguno de los poderes participantes de este orden podía realizar completamente sus pretensiones. Este orden pervive en el siglo XVI y XVII. En el caso de España e Indias son los Borbones los que ponen término a esta situación de equilibrios. Siendo el mejor ejemplo de ello la política regalista.

${ }^{70}$ Lastarria, J. V., Historia constitucional, cit. (n. 5), p. 6.

${ }^{71}$ Ibíd., p. 54-55.

${ }^{72}$ Ibíd., pp. 34-35.

${ }^{73}$ En este punto Lastarria hace un manejo muy acomodaticio de la historia. El episodio al que se refiere no es propiamente una propuesta de paz, sino la decisión de la Corona de acabar con la política de la guerra defensiva. La política de la guerra defensiva era apoyada por el virrey del Perú, y el rey pues implicaba mandar alrededor de 60.000 ducados oro menos al año a Chile. El abastecimiento del ejército había generado una serie de intereses alrededor del Real Situado proveniente del Perú. Como parte de esa política de apaciguamiento, el virrey, príncipe de Esquilache, siguiendo la propuesta de padre Luis de Valdivia dictó una nueva tasa de encomienda que derogó el servicio personal del indígena, sustituyéndola por un pago anual en dinero. Tal situación implicaba cambiar toda la estructura laboral y productiva de Chile. Obviamente tal medida generó la oposición de los vecinos de las ciudades y de los encomenderos. Estos se quedaban sin el trabajo gratuito de los aborígenes y además se sentían traicionados pues la Corona gozaba de ese territorio gracias al mérito y esfuerzo de sus ascendientes. Por ello el cabildo de Santiago pidió inmediatamente al gobernador interino su suspensión. Paralelamente, 
locales tenían en la continuación de la guerra de Arauco $^{74}$.

En este punto, Lastarria reconoce que España fue hasta comienzos de la edad moderna un país en que las instituciones liberales tenían un importante desarrollo; pero que este se habría acabado producto de la reforma del año 1517. En ese momento la constitución mixta, ante el temor del advenimiento del protestantismo, se transformó en una dictadura del trono y la Iglesia. ${ }^{75}$ La relación entre esas entidades y el fundamento de legitimidad que la Iglesia le habría proporcionado al Estado, le restan valor al proto-constitucionalismo hispano ${ }^{76}$.

Al ser ese hecho coetáneo con la colonización de América, la institucionalidad y el espíritu cívico que recibe el nuevo mundo no son el de la España medieval sino la de Carlos V, un monarca absoluto ${ }^{77}$. Por ello, sostiene el autor en cuestión que la participación política era algo extraño en América Latina. La cultura jurídica y política que se habría desarrollado en estas áreas fue la de sumisión. El poder municipal hispano venía en retirada cuando los conquistadores cruzaron el Atlántico ${ }^{78}$.

En este punto, somos de la opinión que Lastarria reprodujo de manera directa cierto idealismo que hubo en parte de los diputados gaditanos. Como dijo Tomás y Valiente, más allá del recurso a la tradición como táctica para disimular las novedades revolucionarias "había entre los autores de la constitución una ingenua y al parecer sincera mitificación de la historia medieval, que les llevó a creer en una Edad Media llena de libertades y garantías después sofocadas por la Monarquía absoluta"79.

Desgraciadamente, la obra de Lastarria no trata los efectos, vigencia y valor

el gobernador interino, el oidor de la Real Audiencia, Cristóbal de la Cerda, constató que los resultados de la guerra defensiva no eran los esperados. Los mapuches no se habían pacificado. Por el contrario, producto del retiro de las milicias hispanas al norte del río Biobío estos se habían envalentonado y atacaron una serie de fuertes y cuarteles en la zona de Yumbel. La evangelización tampoco había dado los frutos esperados; pues los aborígenes, aunque se habían bautizado, no se habían cristianizado. La petición del gobernador no fue escuchada. Por el contrario, el virrey, al percibir la manifiesta oposición del gobernador de la Cerda a la Guerra defensiva optó por designar a otro gobernador, oriundo del Perú, Osores de Ulloa, quien ratificó el fracaso de esa política. En este caso, aunque no se puede desconocer que había intereses económicos de por medio, lo que primó fue la necesidad de proteger los territorios al norte del Biobío y dar a entender que esa política no había traído los resultados esperados. El hecho que el cabildo de Santiago paralelamente haya solicitado la suspensión de la tasa del príncipe de Esquilache demuestra, contrariamente a lo que sostiene Lastarria, la existencia de un Sistema de frenos y contrapesos en la mal llamada monarquía absoluta. A mayor abundamiento; véase BARROS ARANA, Diego, Historia general de Chile (reimpresión Santiago, Editorial Universitaria, 1999), IV, pp.119-145.

${ }^{74}$ LASTARria, J. V., Investigaciones, cit. (n. 15), pp. 26 ss.

${ }^{75}$ Ibíd., p. 57.

${ }^{76}$ Lastarria, J. V., Historia constitucional, cit. (n. 5), p. 3.

${ }^{77}$ Ibíd., p. 58.

${ }^{78}$ En este punto es necesario precisar que estudios posteriores han demostrado que los conquistadores trajeron su propia cultura jurídica, que la gran mayoría de las veces no era la de las grandes ciudades, en las cuales efectivamente esta cultura autoritaria se asentó, sino la de sus aldeas de origen, que aún conservaban las tradiciones jurídicas forales.

${ }^{79}$ TOMÁs y Valiente, Francisco, Manual de historia del derecho español (4a edición Madrid, Tecnos, 2004), p. 439. 
de la constitución mixta ni sobre los postulados formulados tanto por la doctrina medieval o como por la moderna, anteriores al siglo XVIII. Él explica los cambios acaecidos en Europa con ocasión del Congreso de Viena y la resistencia que opusieron los pueblos europeos a las exigencias que formularon las casas reinantes sin la menor alusión a las tradiciones, hábitos y valores jurídicos. Así omite de manera absoluta la valoración que hacen los pueblos de su propio derecho cuando relata el caso de Bélgica y el intento del monarca de copiar para dicho país la carta fundamental holandesa o cuando explica lo sucedido con Polonia bajo la dominación rusa.

En lo tocante al mundo hispano hablante, la obra de Lastarria, aparte de hacerse eco de la leyenda de un medioevo repleto de libertades, desconoce cualquier forma de participación política durante la época indiana. Para él, el único sistema que permitió la representación y deliberación política de la comunidad con anterioridad al constitucionalismo era el sistema foral medieval.

g) Monarquía absoluta. El paradigma del sistema político errado para Lastarria, como ya se dijo, es la monarquía absoluta. El monarca representaba todo en América Latina. Él dictaba las normas de acuerdo a sus intereses, sin tener en cuenta los de la nación. Todos los ramos de la administración estaban sujetos a su voluntad y discrecionalidad ${ }^{80}$. Esta forma de gobierno es denominada en sus libros "despotismo teocrático" en muy pocas manos y la elevación de la intolerancia religiosa y el fanatismo. La monarquía absoluta es representada por la tríada: Dios, Iglesia y armas ${ }^{82}$. En ese sentido la desgracia para América y Chile comienza con la de los Reyes Católicos. A riesgo de ser majaderos repetimos que, acorde con su visión del mundo, para Lastarria antes de ese reinado y el de su sucesor, los reinos hispanos habrían sido sistemas jurídicos y políticos de carácter liberal.

La monarquía absoluta marcó a Chile hasta el momento en que estos libros se escribían; pues el indígena, a excepción del mapuche, tampoco tenía una cultura de las libertades. Aborígenes y españoles poseían una cultura de sumisión y avasallamiento. Por eso Chile era terreno fértil para la monarquía absoluta ${ }^{83}$. Tal situación sería la explicación del débil rol del cabildo en Chile en comparación con la península ibérica ${ }^{84}$. Dicha carencia de educación cívica y de espacios institucionales de participación política había permitido toda clase de arbitrariedades y abusos. Por ello los chilenos se habrían acostumbrado a esperarlo todo de la autoridad $^{85}$.

La corriente liberal es de la idea que la independencia no habría traído ningún cambio cualitativo en la vida de los chilenos. Muchos de los problemas relacionados con el absolutismo pervivían en el Chile republicano. Por ello, la

\footnotetext{
${ }^{80}$ Lastarria, J. V., Historia constitucional, cit. (n. 5), p. 30.

${ }^{81}$ Ibíd., p. 84.

${ }^{82}$ Ibíd., p. 61.

${ }^{83}$ Ibíd., p. 64.

${ }^{84}$ Ibíd., p. 65.

${ }^{85}$ Ibíd., p. 68.
} 
superación de los hábitos y prácticas propias de la monarquía absoluta era tarea del constitucionalismo ${ }^{86}$.

Lastarria analiza la monarquía absoluta en Europa a raíz de las consecuencias del Congreso de Viena y del incumplimiento de las promesas hechas a varios de los pueblos que se vieron de nuevo sometidos a las casas reinantes, como Würtemberg, Baviera y Polonia. Se usan esos casos para mostrar cuán aleve y falta de respeto por su propia palabra es la monarquía absoluta. Es el sistema perverso por antonomasia.

h) Concepción de la historia constitucional y sus consecuencias. Como en todo proyecto de carácter político, el uso de la historia como medio para prestigiar o desacreditar a figuras y autoridades jugó en la obra de Lastarria un papel relevante. Como ya se ha mencionado insistentemente, su proyecto liberal y republicano se basó en la condena a todo aquello que oliese a hispano. Hispanidad fue sinónimo de oscurantismo. Los representantes del conservadurismo eran, por ende, representantes del oscurantismo.

El concebía la historia como una filosofía normativa capaz de dar consejos infalibles ${ }^{87}$. Lo que le interesaba a Lastarria eran las ideas, su evolución, su genealogía ${ }^{88}$. Las ideas que le interesaban eran las de cada pueblo en particular. Sin embargo, ese interés no tenía como objeto un mejor entendimiento del pasado sino un lineamiento del futuro, acorde con los objetivos y problemas del tiempo presente. Por esa razón, ser filósofo de la historia significaba acomodar el pasado a la realidad e intereses del presente. En su opinión, la rama de la historia que permitía de mejor manera conocer el espíritu, las costumbres, ideas y mentalidad de un pueblo era la historia constitucional ${ }^{89}$. El la entroncaba con la historia social $^{90}$. El autor en comento daba, al menos cuando joven, por sentado que las constituciones políticas representaban la esencia de un pueblo. La constitución era el espejo de su pueblo ${ }^{91}$.

Por esa razón, criticar las constituciones y contrastarlas con un arquetipo era -en su opinión- la mejor forma de reformar la sociedad. Pero esa crítica era

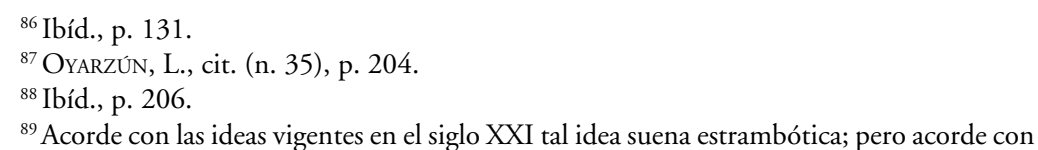
las ideas existentes en el siglo XIX la dictación de una nueva constitución significaba la reforma completa de la sociedad, la recepción de nuevas ideas y en muchas ocasiones encarnaban los anhelos de libertad de las elites. Constitución era sinónimo de autonomía. Por esa razón, no se concebía nada más importante que ello.

${ }^{90}$ Oyarzún, L., cit. (n. 35), p. 210.

${ }^{91}$ Este fue otro de los puntos importantes de la polémica arriba citada entre Andrés Bello y Jacinto Chacón. Andrés Bello discutió la validez de tal aseveración. El partía de la base que la constitución es un papel redactado normalmente por un grupo de juristas y eruditos que en ningún caso era representativos del espíritu de la sociedad, en razón de su mayor instrucción. Asimismo reforzaba su afirmación acerca de la puerilidad de tal idea sobre la constatación de que parte importante de las constituciones hasta ese momento dictadas estaban inspiradas en modelos procedentes de otros países, de distintas costumbres, religión e idioma. Es así como se pregunta si por el hecho que una constitución contenga una serie de instituciones copiadas de la Constitución de Estados Unidos era ese pueblo semejante al pueblo norteamericano. 
formulada desde una óptica mucho más filosófica que jurídica. En consecuencia, la historia constitucional es para Lastarria un asunto de contingencia política. Por la naturaleza siempre vertiginosa y siempre cambiante de tal contingencia, es entendible que no hubiese gran precisión en el uso de vocablos, como liberal, conservador, reformista o reaccionario. No era útil precisar estos conceptos. Definir aquellos conceptos implicaba restar ductilidad a esa disciplina. La consecuencia de una definición era inevitablemente la reducción de las posibilidades de uso de la historia constitucional.

Consecuencia de ello son una serie de imprecisiones que es útil traer a colación. En primer lugar no deja de ser llamativo el trato que dentro se da a O'Higgins y Carrera. Al primero lo denomina jefe del bando de los moderados o faltos de carácter durante la patria vieja, para luego tildarlo de jefe de los conservadores y de dictador mientras al segundo se lo clasifica como jefe del bando reformista ${ }^{92}$. Poco importaron al momento de formular esta categorización una serie de medidas que implicaban la concretización de los ideales ilustrados, como la creación de cementerios independientes de las Iglesias, la abolición de los títulos de nobleza o el intento de iniciar una reforma en el sistema educativo. Tampoco hace una mención a la oposición de O’Higgins a las tratativas de San Martín para ofrecer a alguna casa reinante europea los países del cono sur como una corona independiente. Motejado de conservador era todo aquel que ejercía el poder de manera unipersonal. ${ }^{93}$ Por ello se lo llega a tildar de amigo de la monarquía ${ }^{94}$.

Para Lastarria todas las constituciones que había tenido Chile hasta ese momento eran contrarias a los principios liberales. La crítica efectuada por parte importante de la doctrina carece de criterio histórico. No se hace cargo de la evolución de la idea sobre liberalismo a lo largo del siglo XIX. Por lo mismo, Lastarria no le reconoce a todos los documentos con el encabezado de constitución dicho carácter. Paradigmática de lo anterior es la Constitución de 1818. "Ella organizaba un gobierno que estaba bien lejos de satisfacer el espiritu y las tendencias de la revolución de la independencia" "S. Se corresponde muy bien con las necesidades de su época. La formación de los estados en lo que fue la América indiana se produjo bajo la sinonimia de la guerra de la emancipación con la república.

Las mismas críticas eran válidas para la Constitución de 1822. No hay una sola palabra sobre el modelo en el que se inspira. No se hace ninguna relación entre ella y la de Cádiz de 1812 .

Sobre la Constitución de 1823 su opinión fue ambivalente. Partía de la base

${ }^{92}$ Lastarria, J. V., Historia constitucional, cit. (n. 5), p. 217.

${ }^{93} \mathrm{La}$ crítica que la doctrina constitucional hace a O’Higgins tiene un carácter abiertamente sesgado. Todos los gobiernos en la América española aprendieron que sólo un gobierno unipersonal podía dar solución a los problemas que traía aparejado un estado de guerra. El proceso de aprendizaje que el gobierno republicano importó la necesidad de gobernarse escuchando a las mayorías, entendiendo que la fuente última del poder es la soberanía; pero sin olvidar que a las multitudes había que contenerlas. Como ya se ha dicho, la organización republicana constitucional era contramayoritaria.

${ }^{94}$ Lastarria, J. V., Historia constitucional, cit. (n. 5), p. 406.

${ }^{95}$ Ibíd., p. 231. 
que esa Constitución se inspiraba en el proyecto constitucional de $1811^{96}$, al que consideraba en un comienzo una perla del primer constitucionalismo chileno. Tanta importancia le atribuía Lastarria a ese proyecto que llegó a transcribirlo de manera completa en su libro sobre el desarrollo constitucional en Chile durante la patria vieja. Dicho proyecto reflejaba los denodados esfuerzos por progresar y avanzar en la senda de la libertad, para pocos años después motejarla de una reencarnación del Estado absoluto ${ }^{97}$.

Lastarria tampoco apreciaba las bondades de las llamadas transiciones o reconciliaciones políticas. Él rechazaba la idea de que Chile se salvó de la anarquía y el caos por el hecho de haberse producido una transacción entre los sectores aristocráticos y monárquicos, por una parte, y los liberales y demócratas por otro. La mejor muestra de ello serían las guerras civiles que sacudieron a Chile en el siglo $\mathrm{XIX}^{98}$.

Obviamente, su opinión sobre la carta fundamental del año 1833 nunca fue buena, pero acorde envejecía su opinión sobre ésta se tornó cada vez peor Es así como en la declaración programática del partido liberal de 1850, la considera "el código mejor calculado para los antecedentes y circunstancias en que se promulgó, por cuanto sólo por su medio podía regularizarse y fortificarse el poder del Estado, que entonces necesitaba de la fuerza para mantener la tranquilidad pública [...]"99 para luego terminar considerándola una carta contrarrevolucionaria, que había logrado darle legitimidad a la herencia indiana. Reconoce que la "revolución" independentista aspiraba a una reforma completa sin saber cómo; pero que pretendía "un gobierno que fuese todo lo contrario a la monarquía, que no fuese absoluto, absorbente ni despótico, que no asumiese la dirección omnímoda de todas las creencias, de todos los intereses como el gobierno colonial' 100 .

La valoración que hace Lastarria de esa Constitución va muy de la mano con una descalificación a todo lo que huela a conservador o autoritario. Él sostiene que el movimiento juntista tenía objetivos: evitar todo lo que criticaba del mundo indiano; pero de ahí no se deduce que la república haya sido el objetivo de los independentistas. Tampoco valora el hecho de contar con una constitución escrita ni la impersonalidad del poder que esa Constitución plasmó. Para el caso de Chile no hay ninguna valoración del proceso de evolución -lógico si se interpreta la historia como un aprendizaje- como sí lo hizo al momento de estudiar el caso mexicano y el plan de Iguala. Se extraña un esbozo de crítica al actuar gubernamental del "pipiolaje". Asimismo no hay ninguna valoración al hecho

${ }^{96}$ Ibíd., p. 435. Es una afirmación muy discutible. El redactor de la Constitución de 1823 y del proyecto de 1811, Juan Egaña, vivenció en el período de la reconquista un fuerte cuestionamiento hacia lo que fueron sus ideas en el primer período. En ese confió en las masas; después de la reconquista su planteamiento era abiertamente contra-mayoritario. Ese mayor énfasis liberal; no obstante, convivía con la idea de fundar una monarquía constitucional. En la Constitución de 1823 no hay nada parecido a un monarca.

${ }^{97}$ Lastarria, J. V., Historia constitucional, cit. (n. 5), p. 421.

${ }^{98}$ Ibíd., pp. 434-435.

${ }^{99}$ Errázuriz Zañartu, Federico - Lastarria, José Victorino, Bases de la reforma (Santiago, Imprenta del Progreso, 1850), p. 8.

${ }^{100}$ Lastarria, J. V., Lecciones de política positiva, cit. (n. 17), p. 77. 
que Chile, bajo la Constitución de 1833 ya era un Estado consolidado. No hay mención a la república como objetivo inmediato del movimiento juntista en la América indiana. La mejor prueba de esta afirmación la constituyen las mismas palabras del autor: "La contrarrevolución está organizada, está fortificada en nuestra constitución política y en las leyes represivas que en este código hallan su base y punto de partida"101.

Él reconoció, sin embargo, que esta pervivencia de las ideas indianas en la elite se debía antes que nada a la educación que este grupo recibía. El sostenía que el estudio de latín, historia antigua, la cultura clásica y la filosofía romana y griega conducían a una fascinación por instituciones contrarias a los principios liberales ${ }^{102}$.

\section{CONCLUSIONES}

Nuestras conclusiones se pueden sintetizar así:

$1^{\circ}$ Es claro que José Victorino Lastarria como jurista y profesor de derecho intentó sentar las bases para la creación de un derecho patrio que superase la herencia indiana. Para ello esgrimió fuertes críticas al pasado hispano y al derecho indiano.

$2^{\circ} \mathrm{El}$ área del derecho por la que él preferentemente se interesó y en la que se pueden apreciar de mejor manera sus dotes creativos fue el derecho público. Este debía ajustarse a los parámetros fijados por el constitucionalismo y basarse en un respeto absoluto por la libertad, como fin último del ordenamiento jurídico.

$3^{\circ} \mathrm{La}$ fundamentación de su propuesta liberal y el uso que en ella hace de la historia es variada e interesante. Recurre de manera asidua a la historia del derecho comparado y destaca los logros, aciertos y fracasos del mundo occidental en su desarrollo jurídico. Destacable es advertir cuán al tanto estaba de lo que ocurría en el mundo y la valoración que hace del proceso de cambios que vivían Europa y América Latina desde el comienzo de las revoluciones decimonónicas.

$4^{\circ}$ Como político y profesor de derecho logra darle al derecho constitucional un carácter épico. Es el derecho revolucionario del siglo XIX. Es para él el derecho del cambio social, el de la liberación de los pueblos oprimidos y el medio jurídico para emancipar al hombre en cuanto persona con cuerpo, mente y espíritu.

$5^{\circ}$ El uso que hace de la historia es ambivalente, pero funcional a la necesidad de forjar un Estado-nación con un derecho patrio propio. Su acercamiento al derecho constitucional en cuanto proceso histórico desde la tesis del aprendizaje político fue morigerado con el paso del tiempo, al constatar los problemas que estos textos experimentaban a la hora de implementarse. Dicho planteamiento se corresponde muy bien con su carácter de ideólogo y filósofo de la historia. Por esa razón sus críticas y propuestas de mejoras pasaban solamente por una mejora de la técnica legislativa y una mayor minuciosidad en la regulación que estas contenían.

$6^{\circ}$ A la luz de los estudios sobre derecho indiano de nuestros tiempos queda claro que este, con sus defectos y ventajas, era mucho más que un mero medio de control social que la corona ideó para mantener sometidos a los reinos de este

\footnotetext{
${ }^{101}$ Ibíd., p.77.

${ }^{102}$ Lastarria, J. V., Historia constitucional, cit. (n. 5), pp. 429 ss.
} 
continente. Este derecho tenía fines y medios de solución de conflictos propios que permearon la mentalidad y la idiosincrasia jurídica mucho más allá del término del proceso de emancipación política. El derecho indiano fue mucho más que las varias veces acertadas críticas formuladas por el autor en estudio.

$7^{\circ} \mathrm{La}$ misma imposibilidad de entender cabalmente qué fue el derecho indiano le permitió comprender solo de manera parcial las peculiaridades del derecho constitucional en este continente. Al tener una visión tan simple del derecho indiano no logra explicar las causas de la concentración de funciones en el ejecutivo ni tampoco entender las causas del autoritarismo político. Su análisis histórico va desde el pragmatismo y la aceptación de la realidad en algunos aspectos hasta la completa negación de esta, con la esperanza que en el futuro todo marcharía de acuerdo a lo que él pensaba debía ser el mundo.

$8^{\circ}$ Como consideración preliminar, pues falta estudiar su labor como parlamentario, se podría aventurar que su mayor aporte se da principalmente en el campo de las ideas.

$9^{\circ}$ Las citas que hace de la doctrina y al derecho comparado se centran en Inglaterra, Estados Unidos y Francia como arquetipos de lo que debe ser un Estado constitucional; pero no olvidó otros polos de desarrollo jurídico como lo fueron España y Alemania, ni tampoco dejó de recurrir a los buenos ejemplos latinoamericanos.

$10^{\circ}$ José Victorino Lastarria tuvo siempre a la vista la doble dimensión del derecho constitucional. Trató de destacar las particularidades nacionales, generalmente desde un punto de vista negativo para el caso de Chile, sin olvidar los grandes principios comunes a todos.

$11^{\circ}$ Para él, más importante que el texto de la constitución y las prácticas políticas era el reconocimiento y consagración de los nuevos principios. Esta manera tan poco crítica de acercarse a la letra de la norma es particularmente palmaria al juzgar la Constitución de Cádiz de 1812.

\section{BiBLIOGRAFÍA}

De Ávila Martel, Alamiro - Rebolledo Hernández, Antonia, "Bibliografía.” En VV. AA., Estudios sobre José Victorino Lastarria (Santiago, Ediciones Universidad de Chile, 1988).

Barrientos Grandón, Javier, Lastarria y el derecho, en VV. AA., Estudios sobre José Victorino Lastarria (Santiago, Ediciones Universidad de Chile, 1988).

Varas Alfonso, Paulino, Homenaje a los profesores José Victorino Lastarria y Jorge Hunneus en los 170 años de enseñanza del derecho constitucional, en Revista de Derecho Público, 79 (2013).

LASTARria, José Victorino, Historia constitucional de medio siglo (Santiago, Imprenta del Mercurio, 1853).

BRISEÑo, Ramón, Memoria Histórico-crítica del derecho público chileno desde 1810 hasta nuestros días. Obra presentada a la Universidad de Chile en la sesión solemne del 14 de octubre de 1849, con la que celebró el sexto aniversario de su instalación (Santiago, Imprenta de Julio Belin, 1849).

GaY, Claudio, Historia fisica y politica de Chile, según documentos adquiridos en esta 
República durante doce años de residencia en ella y publicada bajo auspicios del supremo Gobierno (Paris, Casa del Autor. En Chile Museo de Historia Natural, 1844-1876), VIII.

Lastarria, José Victorino, Bosquejo histórico de la Constitución del Gobierno de Chile durante el primer periodo de la revolución desde 1810 hasta 1814 (Santiago, Imprenta Chilena, 1847).

Bello, Andrés, "Constituciones", en El mISMO, Escritos jurídicos, políticos y universitarios (Squella Narducci, Agustín compilador, Valparaiso, EDEVAL, 1979).

LASTARRIA, José Victorino, Investigaciones sobre la influencia social de la conquista y del sistema colonial de los españoles en Chile (Santiago, Imprenta del Siglo, 1844).

LASTARrIA, José Victorino, Lecciones de política positiva (Santiago, Imprenta de El Ferrocarril, 1874).

Westermeyer Hernández, Felipe, La desamortización de los bienes de regulares en Chile: la primera discusión jurídica del derecho patrio sobre la naturaleza y alcance del dominio, en Revista Chilena de Historia del Derecho, 22 (2010) 2.

Oyarzún, Luis, El pensamiento de Lastarria (Santiago, Editorial Jurídica de Chile, 1953).

SuberCaSeaux, Bernardo, La América de José Victorino Lastarria y las ideas de Courcelle Seneuill, en Revista de Derecho y Humanidades, 8 (2001).

Pietschmann, Horst, Actores locales y poder central: la herencia colonial y el caso de México, en Relaciones, 73, (Invierno de 1998, XIX).

Barros Arana, Diego, Historia general de Chile (reimpresión Santiago, Editorial Universitaria, 1999), IV.

Tomás y Valiente, Francisco, Manual de historia del derecho español (4a edición, Madrid, Tecnos, 2004).

Errázuriz ZaÑartu, Federico - LaStarria, José Victorino, Bases de la reforma (Santiago, Imprenta del Progreso, 1850). 
